\title{
Economics and Management of Agricultural Production in the Republic of Bashkortostan in the Context of the COVID Pandemic
}

\author{
Alfiya KUZNETSOVA \\ Bashkir State Agrarian University, Ufa, Russia; alfia_2009@mail.ru
}

\begin{abstract}
Taking into account all existing opinions on food security and generally agreeing with them, in our work we are faced with the task of defining directions for the development of agricultural production in one of the 85 regions of the Russian Federation- in the Republic of Bashkortostan. The main purpose of this paper is to identify the key directions for the development of the agricultural sector, taking into account the situation of Covid for the period up to 2030. Agriculture of the Republic of Bashkortostan is one of the leading in the Russian Federation with $3.4 \%$. For the main types of food: milk, meat, potatoes, vegetable oil and sugar, the region is completely independent. Despite the situation with Covid, in 2020 the region increased its agricultural production by $5 \%$. the average monthly wage of agricultural producers is about $30 \%$ less than the wages of workers in processing industries. In turn, the level of remuneration of workers in the agricultural sector is on average $56-58 \%$ of the average for the region, in food processing industries - about $79 \%$. It is quite obvious that an insufficiently high level of attractiveness of work in the agro-industrial complex leads to an outflow of qualified personnel to other industries. But to 2025-2030 the Republic of Bashkortostan needs an increase in the production of vegetables - not less than $30 \%$, fish $77 \%$, fruits, berries - in 3-4 times.
\end{abstract}

Keywords: food; security; agro-industrial; production; level of consumption

JEL Classification: O3; Q13

\section{Introduction}

The issues of ensuring food security through the creation of conditions for sustainable development of rural areas have been paid attention in the works of various scientists and researchers: Bouwman De CaZK et al. (2021), Godfray et al. (2010), De Carvalho et al. (2021), Drangert (2021), Farcas et al. (2021), Neelakantan, DeFries, and Fanzo (2020), O'Hara and Toussaint (2021) and many others.

In our opinion, in modern conditions the world is faced with three key contradictions that hold back the progressive development of agro-industrial production. The first contradiction boils down to the fact that the growth of agricultural production directly depends on the problem of climate warming, significant temperature changes and often recurring unpredictable natural phenomena (Kassie \& Alemu, 2021), as well as on the processes of intensification of agricultural production (Mishra et al., 2021). Secondly, some scientists (mainly from southern countries), considering food security, pay attention to water 
scarcity as a key factor constraining the growth of crop yields. (Drangert, 2021). The third controversy that impedes effective food security management is the occurrence of frequent floods, «which cause a loss of household income and contribute to an increase in the level of poverty» (Oskorouchi \& Sousa-Poza, 2021).

Another new contradiction that had a serious impact on the economic recession and the deterioration of the management processes of agro-industrial production was the Covid-19 pandemic. It attracted the attention of scientists around the world of completely different scientific fields and all types of economic activity. For example, Brazilian academics note that «measures to directly purchase food from family farmers, deliver school food kits directly to students, and exemptions from paying electricity bills for vulnerable persons and other emergency measures were not coordinated enough to contain the food crisis in Brazil» (Carvalho et al., 2021; Kansiime, 2021). O'Hara and Toussaint (2021) writes about the constant disparity in the population's access to food.

The full interconnection of factors «water-food-energy, as a tool for increasing productivity and sectoral policy», write in their work (Beekma et al., 2021), emphasizing «the need to search for tools to increase productivity and sectoral policy, in order to avoid unforeseen consequences». European scientists examine the interconnectedness «of food management issues during a pandemic crisis, and the need to maintain a sound food security system, by adopting the right strategies to match the needs and requirements of consumers with the requirements of food safety, manufacturers, distribution chain, economic environment, and waste management» in an integrated manner, through bioeconomics.

Taking into account all existing opinions on food security and generally agreeing with them, in our work we are faced with the task of studying the processes of managing agroindustrial production in one of 85 regions of the Russian Federation - in the Republic of Bashkortostan, agriculture has occupied a leading position over the past 50 years.

\section{Methodology}

The work used statistical, tabular and graphical methods for researching the analysis of the current situation in the agroindustry. The information base of the study was made up of official data from the statistical services of the Russian Federation and the Republic of Bashkortostan. The main purpose of this article is to identify the key directions for the development of the agricultural sector, taking into account the situation of Covid for the period up to 2030. At the first stage of the study, we assessed the level of food self-sufficiency in the region against the background of national indicators. At the second stage, we assessed the degree of utilization of production capacities for processing agricultural products. At the third stage of the research, we compared the level of profitability of the functioning of agricultural and processing enterprises. At the fourth stage of the study, we calculated the required volume of production of the main types of agricultural products in the region for the period up to 2030 . 


\section{Results}

Agriculture of Bashkortostan is a branch of the economy of the Republic of Bashkortostan. Agriculture of the Republic of Bashkortostan is one of the leading in the Russian Federation. With 3.4\% (7.069 million hectares, arable land - 3,636.7 thousand hectares) of agricultural land in Russia, the republic produces $3.2 \%$ of all its agricultural products. A comparative analysis of the level of self-sufficiency of the population of the Republic of Bashkortostan shows that for all the main types of agricultural products: meat, milk, potatoes, eggs, vegetable oil, as well as bread and grain products, it is higher than in the whole country (Table 1).

Table 1. Comparative analysis of the level of consumption of basic food products in the Russian Federation and the Republic of Bashkortostan (per capita per year; kilograms)

\begin{tabular}{|c|c|c|c|c|c|c|c|}
\hline Indicators & 2010 & 2015 & 2016 & 2017 & 2018 & 2019 & $\begin{array}{c}2019 / 2010 \\
(\%) \\
\end{array}$ \\
\hline \multicolumn{8}{|c|}{ Potatoes } \\
\hline Russian Federation & 95 & 91 & 90 & 90 & 89 & 89 & 93.7 \\
\hline Republic of Bashkortostan & 78 & 86 & 85 & 87 & 91 & 91 & 116.7 \\
\hline \multicolumn{8}{|c|}{ Vegetables } \\
\hline Russian Federation & 98 & 102 & 102 & 104 & 107 & 108 & 110.2 \\
\hline Republic of Bashkortostan & 70 & 78 & 76 & 76 & 76 & 76 & 108.6 \\
\hline \multicolumn{8}{|c|}{ Fruits and berries } \\
\hline Russian Federation & 57 & 60 & 60 & 59 & 61 & 62 & 108.8 \\
\hline Republic of Bashkortostan & 40 & 44 & 45 & 42 & 41 & 42 & 105.0 \\
\hline \multicolumn{8}{|c|}{ Meat and meat products } \\
\hline Russian Federation & 69 & 73 & 74 & 75 & 75 & 76 & 110.1 \\
\hline Republic of Bashkortostan & 78 & 74 & 76 & 78 & 78 & 78 & 100.0 \\
\hline \multicolumn{8}{|c|}{ Milk } \\
\hline Russian Federation & 245 & 233 & 231 & 230 & 229 & 234 & 95.5 \\
\hline Republic of Bashkortostan & 324 & 297 & 293 & 300 & 300 & 301 & 92.9 \\
\hline \multicolumn{8}{|c|}{ Eggs, pieces } \\
\hline Russian Federation & 270 & 273 & 277 & 282 & 284 & 285 & 105.6 \\
\hline Republic of Bashkortostan & 301 & 272 & 293 & 304 & 301 & 302 & 100.3 \\
\hline \multicolumn{8}{|c|}{ Sugar } \\
\hline Russian Federation & 39 & 39 & 39 & 39 & 39 & 39 & 100.0 \\
\hline Republic of Bashkortostan & 35 & 38 & 37 & 37 & 37 & 37 & 105.7 \\
\hline \multicolumn{8}{|c|}{ Vegetable oil } \\
\hline Russian Federation & 13.4 & 13.6 & 13.7 & 13.9 & 14.0 & 14.0 & 104.5 \\
\hline Republic of Bashkortostan & 13.2 & 15.1 & 15.0 & 15.2 & 15.3 & 15.3 & 115.9 \\
\hline \multicolumn{8}{|c|}{ Bread products } \\
\hline Russian Federation & 120 & 118 & 117 & 117 & 116 & 116 & 96.7 \\
\hline Republic of Bashkortostan & 126 & 120 & 119 & 120 & 121 & 121 & 96.0 \\
\hline
\end{tabular}

Calculated by: The official website of the Federal State Statistics Service of the Russian Federation. Source: https://rosstat.gov.ru/ [Date of access: 10.01.2021]; The official website of the Federal State Statistics Service for the Republic of Bashkortostan. Source: https://bashstat.gks.ru/ [Date of access: 10.01.2021]

The territory of the Republic of Bashkortostan is divided into several agricultural zones, differing in natural and climatic conditions, landscape, soil and vegetation cover. There are six natural and climatic zones in the region: the mountain-forest zone occupies $15.1 \%$ of the territory of the Republic of Bashkortostan; Trans-Ural steppe zone $-13 \%$ of the territory; the 
pre-Ural steppe zone $-26.2 \%$, the northern forest-steppe zone $-20.7 \%$ of the territory, the northeastern forest-steppe zone $-8.2 \%$ of the territory, the southern forest-steppe zone $-16.8 \%$.

Each of the designated zones has its own characteristics of farming and growing plants. For example, buckwheat, sunflowers, legumes are grown in the forest-steppe and steppe zones: red clover (meadow), alfalfa, sainfoin, white sweet clover and yellow sweet clover, Oriental goat's rue (galega), as well as crops of annual crops - mustard and rape.

From the data It follows, that the natural and climatic potential and territorial distribution of the region does not allow to fully increase the production of vegetables, fruits and fish.

The level of food self-sufficiency of the Republic of Bashkortostan has always been and is now quite high, but there is reason to believe that the production potential of the region is not being used effectively enough. Analysis of the level of use of the average annual capacity of enterprises for the production of food products proves this fact (Figure 1).

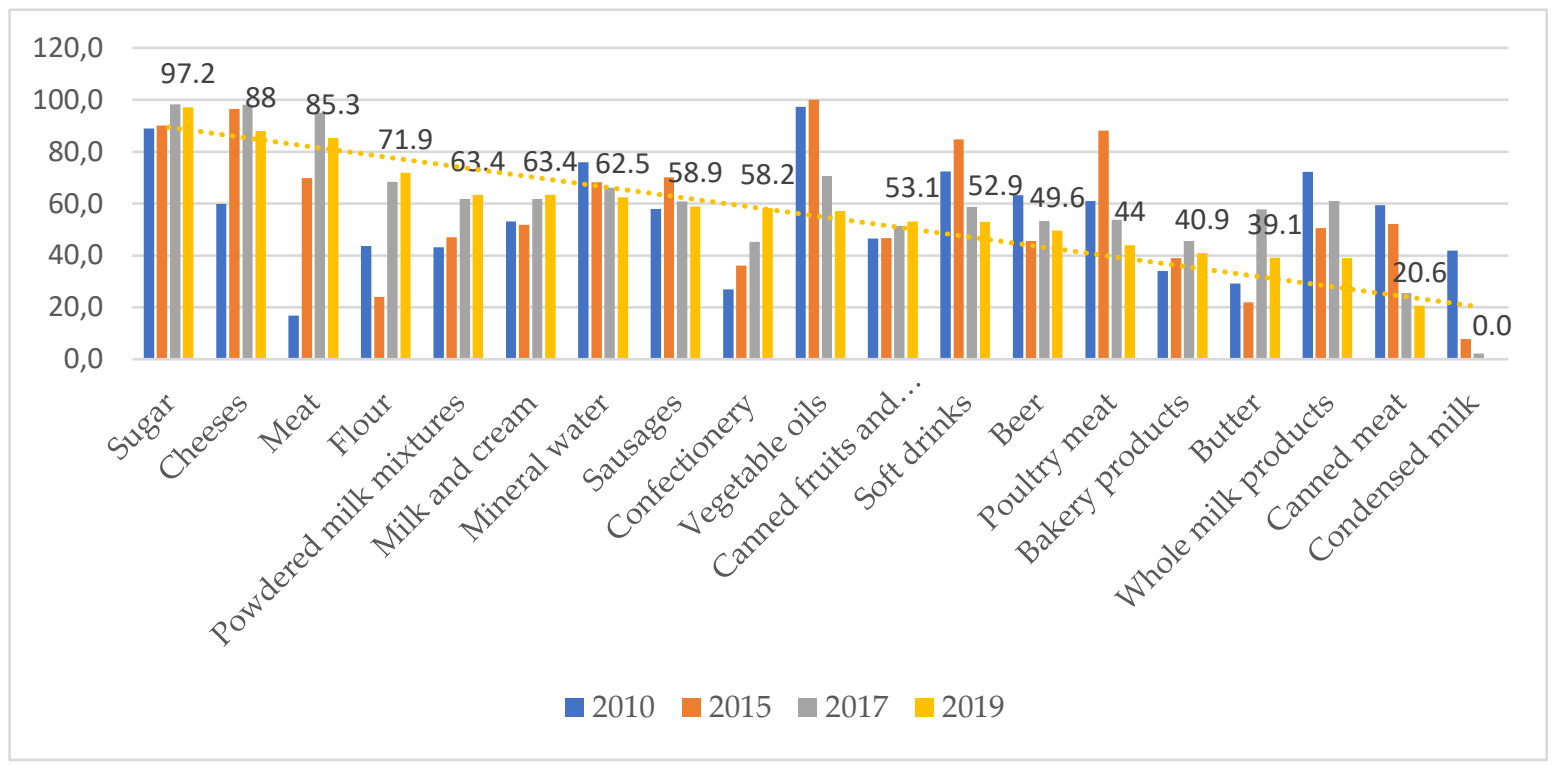

Figure 1. Load capacity of food enterprises in the Republic of Bashkortostan (percent). Calculated by: The official website of the Federal State Statistics Service of the Russian Federation. Source: https://rosstat.gov.ru/; The official website of the Federal State Statistics Service for the Republic of Bashkortostan. Source: https://bashstat.gks.ru/ [Date of access: 10.01.2021]

The level of utilization of the production capacities of food processing enterprises at the level (above the norm) - above 95\% is observed for such types of products as: sugar (98\%) and cheese $(98 \%)$. The republic has a powerful potential for the development of its own production for such types of food as: cereals, condensed milk products (by $88 \%$ ), milk and cream in solid forms (by 81\%), canned fruits and vegetables (by 39\%), beer (by 37\%), meat and by-products (36\%), butter (32\%), soft drinks (31\%), sausages (39\%), whole milk products $(29 \%)$, dry milk mixtures ( $28 \%)$, mineral water $(24 \%)$, flour $(22 \%)$, unrefined vegetable oil $(19 \%)$ and other types of finished food products. It is clear that the region has significant potential to increase the level of utilization of production facilities, at least up to $90 \%$. One of the main reasons for the narrowed reproduction processes in agriculture and the agroindustrial complex is the unprofitableness of some operating industries (Figure 2). 


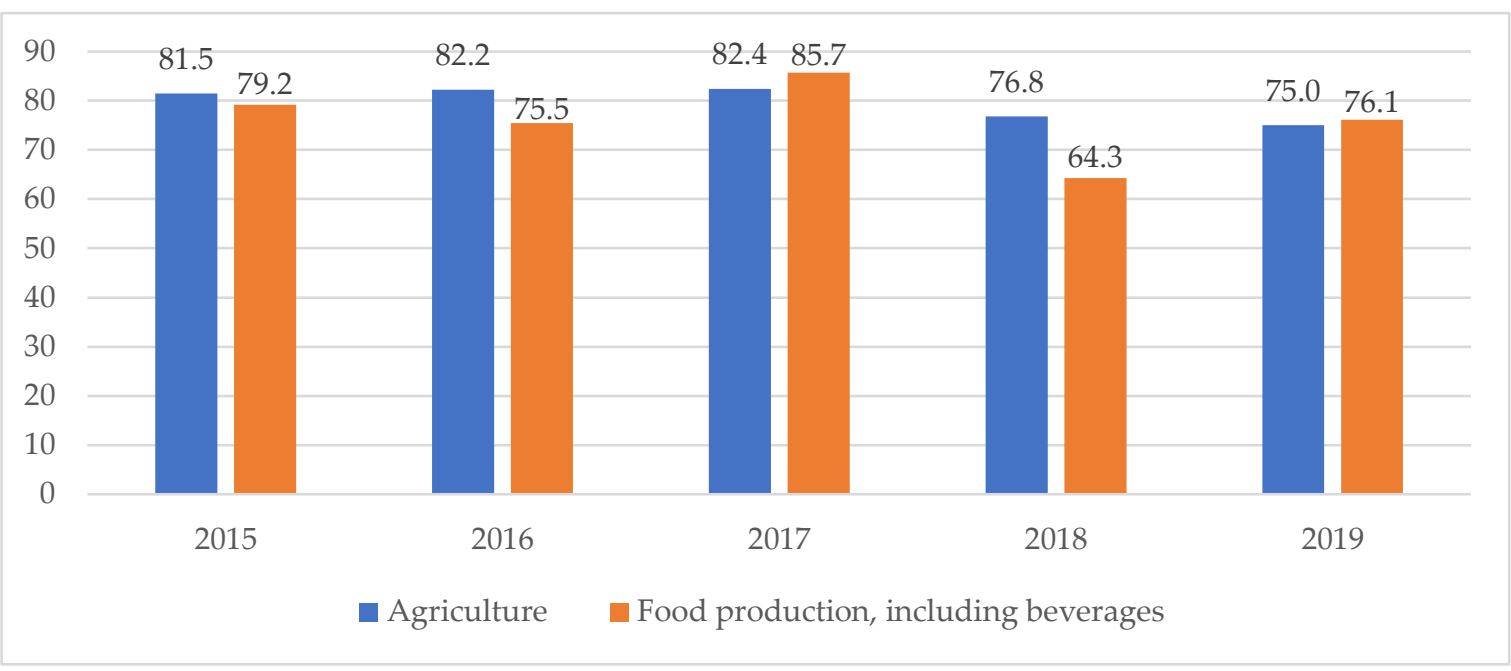

Figure 2. Percentage of profitable organizations as a percentage of the total number of organizations in the Republic of Bashkortostan (in percentage). Calculated by: The official website of the Federal State Statistics Service of the Russian Federation. Source: https://rosstat.gov.ru/ [Date of access: 10.01.2021]; The official website of the Federal State Statistics Service for the Republic of Bashkortostan. Source: https://bashstat.gks.ru/ [Date of access: 10.01.2021]

The actual level of profitable agricultural enterprises decreased from 81.5 to $75 \%$, food processing enterprises - from 79 to $76 \%$. Thus, about $25 \%$ of agricultural and about $26 \%$ of processing enterprises in Bashkiria are unprofitable. The unprofitableness of many agricultural enterprises is associated, first of all, with the low level of purchase prices set by processing enterprises. This leads to a differentiation in the level of remuneration of workers in agricultural and processing enterprises, as well as enterprises of the flour and cereal industry (Figure 3).

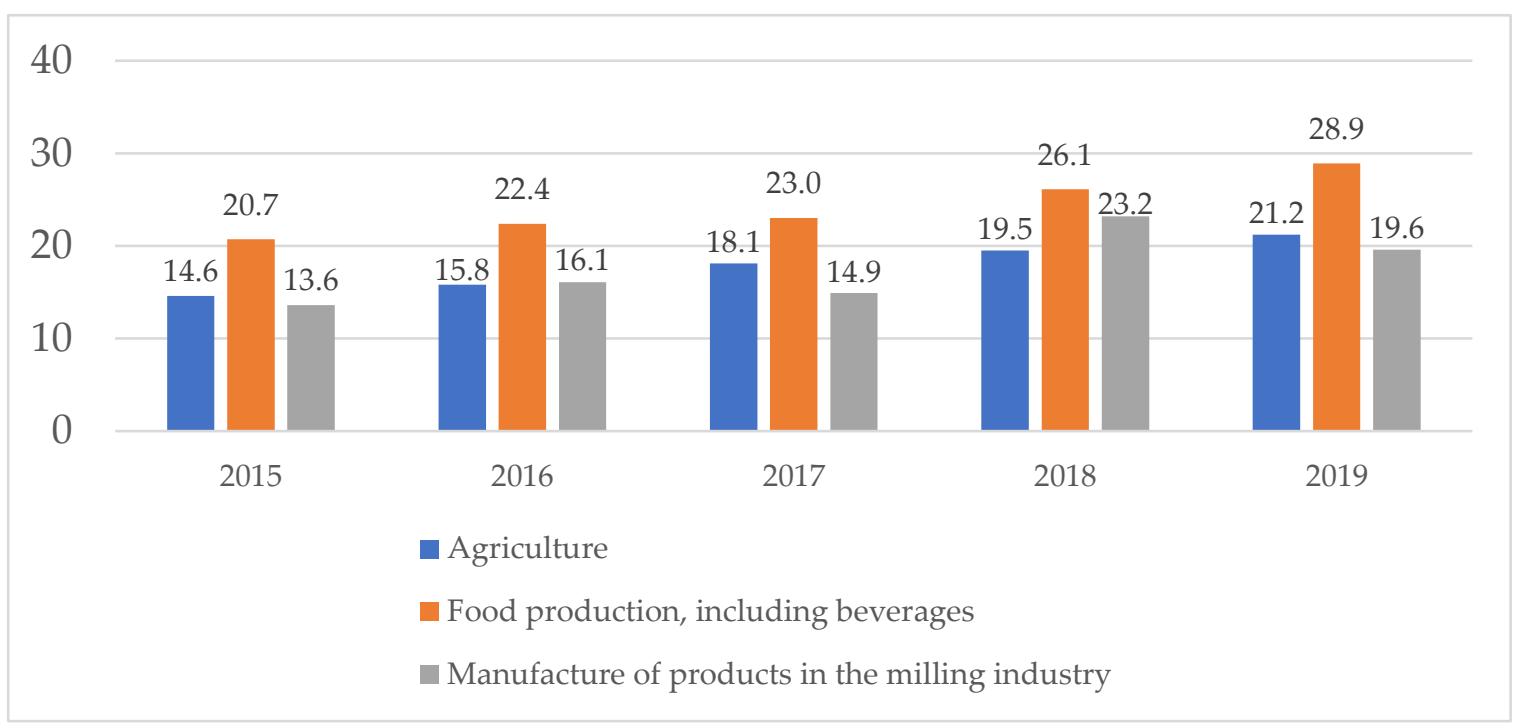

Figure 2. Percentage of profitable organizations as a percentage of the total number of organizations in the Republic of Bashkortostan (in percentage). Calculated by: The official website of the Federal State Statistics Service of the Russian Federation. Source: https://rosstat.gov.ru/ [Date of access: 10.01.2021]; The official website of the Federal State Statistics Service for the Republic of Bashkortostan. Source: https://bashstat.gks.ru/ [Date of access: 10.01.2021] 
The unprofitableness of some food processing enterprises, in turn, is associated with a large number of imported, cheaper food products on the market, winning in terms of pricequality. In addition, it is important to note that the average monthly wage of agricultural producers is about $30 \%$ less than the wages of workers in processing industries. In turn, the level of remuneration of workers in the agricultural sector is on average $56-58 \%$ of the average for the region, in food processing industries - about 79\%. It is quite obvious that an insufficiently high level of attractiveness of work in the agro-industrial complex leads to an outflow of qualified personnel to other industries, where work turns out to be not so hard and tedious, and money is paid in much larger amounts to maintain a decent level and quality of people's life. For import substitution of food, it is necessary to take comprehensive and radical measures, rational use of available land, climatic and labor resources (Kuznetsova et al., 2019a, 2019b).

According to the official forecasts of the official website of the Federal State Statistics Service of the Russian Federation and Federal State Statistics Service for the Republic of Bashkortostan, the population of the Republic of Bashkortostan by 2025 will be about 3,990 thousand people, by $2030-3,860$ thousand people. Calculations of the required volumes of food in Bashkiria by 2025 and by 2030 are presented in Table 2 .

Table 2. Calculations of the required volumes of food in the Republic of Bashkortostan by 2025 and by 2030 (thousand tons)

\begin{tabular}{|c|c|c|c|c|c|c|c|c|}
\hline Indicators & Potatoes & Vegetables & Meat & Sugar & $\begin{array}{l}\text { Vegetable } \\
\text { oil }\end{array}$ & $\begin{array}{c}\text { Fruits } \\
\text { and } \\
\text { berries }\end{array}$ & Milk & Fish \\
\hline $\begin{array}{c}\text { Actual level of production } \\
\text { in all forms of } \\
\text { management (2018), } \\
\text { thousand tons }\end{array}$ & 851.9 & 313.0 & 400.1 & $\begin{array}{c}\text { no } \\
\text { data }\end{array}$ & no data & $\begin{array}{c}\text { no } \\
\text { data }\end{array}$ & 1623.9 & $\begin{array}{c}\text { no } \\
\text { data }\end{array}$ \\
\hline \multicolumn{9}{|c|}{ Required production volumes, taking into account rational consumption rates, thousand tons } \\
\hline 2025 year & 379.1 & 518.7 & 299.3 & 103.7 & 47.9 & 399.0 & 1316.7 & 87.8 \\
\hline 2030 year & 366.7 & 501.8 & 289.5 & 100.4 & 46.3 & 386.0 & 1273.8 & 84.9 \\
\hline \multicolumn{9}{|c|}{ Required production volumes, taking into account the Food Doctrine, thousand tons } \\
\hline Doctrine Indicators, $\%$ & 95.0 & 90.0 & 85.0 & 80.0 & 90.0 & 60.0 & 90.0 & 80.0 \\
\hline 2025 year & 360.1 & 466.8 & 254.4 & 83.0 & 43.1 & 239.4 & 1185.0 & 70.2 \\
\hline 2030 year & 348.4 & 451.6 & 246.1 & 80.3 & 41.7 & 231.6 & 1146.4 & 67.9 \\
\hline
\end{tabular}

Calculated by: The official website of the Federal State Statistics Service of the Russian Federation. Source: https://rosstat.gov.ru/ [Date of access: 10.01.2021]; The official website of the Federal State Statistics Service for the Republic of Bashkortostan. Source: https://bashstat.gks.ru/ [Date of access: 10.01.2021]

Thus, according to the Doctrine of the country's food security, as well as taking into account rational consumption standards, by 2025-2030 the Republic of Bashkortostan needs an increase in the production of vegetables - not less than $30 \%$, fish - 77\%, fruits, berries - in 3-4 times. For the main types of food: milk, meat, potatoes, vegetable oil and sugar, the region is completely independent.

By 2030, the population of the region may decrease by $3.3 \%$, this may entail a decrease in the required volumes of agricultural production, however, while maintaining an exportoriented strategy, it is desirable to maintain an expanded reproductive approach both in agricultural production and in processing industries and the agro-industrial complex. 


\section{Discussion}

Traditionally, the Republic of Bashkortostan was a leader in the production of agricultural products, this has always been favored by natural and geographical conditions and the availability of labor resources. Since the region may well provide agricultural products to neighboring regions, it is necessary to increase the volume of production in largescale forms of management and increase its processing, to intensify marketing and logistics work to promote goods. The republic has significant potential for the development of agriculture. The work of the agro-industrial complex in 2020 was built within the framework of key program documents. These are the State Program "Development of Agriculture", Decree of the Head of the Republic of Bashkortostan No. 310 "On strategic directions of socioeconomic development of the Republic of Bashkortostan until 2024" and national projects related to the development of small business and exports. In addition, in all three packages of anti-crisis measures, agriculture in the region was given special attention, thanks to which in 2020 production growth was about $5 \%$.

It is important to note that in modern conditions there is an urgent need for the development and systematic implementation of the targeted Food Program of Bashkiria for the period up to 2030 .

\section{Conclusions}

For the guaranteed and reliable functioning of the agro-industrial complex of the Republic of Bashkortostan in 2025-2030, it is necessary to increase the land and technicalproduction potential of the region (on average for one year):

- to ensure land growth: for grain crops - by 20-22 percent; for industrial crops - by 10-15 percent; under potatoes - up to 20 percent; under vegetables and fruits - by 25-35 percent; under meadows and pastures for livestock - three times; under grasses and linden trees 2.8-3 times; for crops of chemically pure herbs (for collecting medicinal plants and environmentally friendly beekeeping) - 4-5 times; reclaimed (by all reclamation methods) lands - at least three times;

- to achieve an increase in greenhouse areas: for cucumbers and tomatoes - three times; for other vegetables and fruits - 2.5-2.6 times; under flowers - five to six times;

- to increase the number of livestock (for all types of economic entities), including: cattle (cattle) - 1.7-1.8 times (Kuznetsova et al, 2020); pigs - twice; horses, sheep and goats - 3.54 times (including breeding horses - no less than 8-10 times) (Kuznetsova et al, 2019a; Askarov et al, 2020);

- to increase the number of poultry (for all economic entities) including: chickens - up to 1.5 times; ducks and turkeys - not less than 3.5 times; geese - 2-2.2 times;

- to ensure an increase in the number of bee hives by 2.5-3 times;

- to ensure the increase in the applied fertilizers (by weight): mineral fertilizers - at least three times; organic fertilizers (including processed animal and poultry waste) - 10-12 times; 
- to ensure an increase in the area of rivers and all types of open water bodies with an artificial stocking regime - 4-5 times;

- to ensure an increase in the production of fresh and concentrated feed - at least three times.

These goals can be achieved by increasing labor productivity, strengthening fixed assets and increasing the motivation of workers to work and some other activities.

\section{References}

Askarov, A., Kuznetsova, A., \& Gusmanov, R. (2020). Cost-effective horse breeding in the Republic of Bashkortostan, Russia. Veterinary World, 10, 2039-2045. https://doi.org/10.14202/vetworld.2020.2039-2045

Beekma, J., Bird, J., Mersha, A.N., Reinhard, S., Prathapar, S.A., Rasul, G., Richey, J., Van Campen, J., Ragab, R., \& Perry, C. (2021). Enabling policy environment for water, food and energy security. Irrigation and Drainage. https://doi.org/10.1002/ird.2560

Bouwman, T.I., Andersson, J.A., \& Giller, K.E. (2021). Adapting yet not adopting? Conservation agriculture in Central Malawi. Agriculture ecosystems E environment, 307, 107224. https://doi.org/10.1016/j.agee.2020.107224

De Carvalho, C.A., Viola, PCDF, \& Sperandio, N. (2021). How is Brazil facing the crisis of Food and Nutrition Security during the COVID-19 pandemic? Public Health Nutrition, 24(3), 561-564. https://doi.org/10.1017/S1368980020003973

Drangert, J.O. (2021). Urban water and food security in this century and beyond: Resource-smart cities and residents. Ambio, 78, 963. https://doi.org/10.1007/s13280-020-01480-z

Farcas, A.C., Galanakis, C.M., Socaciu, C. et al. (2021). Food Security during the Pandemic and the Importance of the Bioeconomy in the New Era. Sustainability, 13(1), 150. https://doi.org/10.3390/su13010150.

Godfray, H., Charles, J., Beddington, J. R., Crute, I. R. et al. (2010). Food security: the challenge to feed 9 billion people. Science, 327, 812-818.

Kansiime, M.K., Tambo, J. A., Mugambi, I. et al. (2021). COVID-19 implications on household income and food security in Kenya and Uganda: Findings from a rapid assessment. World Development, R., 137(105199). https://doi.org/10.1016/j.worlddev.2020.105199

Kassie, K.E., \& Alemu, B.A. (2021). Does irrigation improve household's food security? The case of Koga irrigation development project in northern Ethiopia. Food Security. https://doi.org/10.1007/s12571-020-01129-5.

Kuznetsova, A. (2020). Prospects for the Development of the Dairy Industry in the Republic of Belarus and in the Russian Federation. In Hradec Economic Days (vol. 10, pp. 417-425). https://doi.org/10.36689/uhk/hed/2020-01048.

Kuznetsova, A., Avzalov, M., Gogbunov, D., \& Stovba, E. (2019a). Trends and Status of Agribusiness in Animal Husbandry of the Russian Federation. Hradec Economic Days, 9(1), 519-527.

Kuznetsova, A., Kolevid, G., Kostyaev, A. et al (2019b). Reproduction of the Qualified Personnel of Working Professions in Agriculture. In Hradec Economic Days (vol. 9, pp. 11-22).

Mishra, A., Ketelaar, J.W., Uphoff, N., \& Whitten, M. (2021). Food security and climate-smart agriculture in the lower Mekong basin of Southeast Asia: evaluating impacts of system of rice intensification with special reference to rainfed agriculture. International Journal of Agricultural Sustainability. https://doi.org/10.1080/14735903.2020.1866852

Neelakantan, A., DeFries, R., \& Fanzo, J. (2020). Food security and livelihoods of post-resettlement households around Kanha National Park. Plos One, 12, e0243825. https://doi.org/10.1371/journal.pone.0243825

O'Hara, S., \& Toussaint, E.C. (2021). Food access in crisis: Food security and COVID-19. Ecological Economics, Tom 180(106859). https://doi.org/10.1016/j.ecolecon.2020.106859

Oskorouchi, H.R.; Sousa-Poza, A. (2021). Floods, food security, and coping strategies: Evidence from Afghanistan. Agricultural Economics, 52(1), 123-140. https://doi.org/10.1111/agec.126101

The official website of the Federal State Statistics Service of the Russian Federation. (2021). https://rosstat.gov.ru/

The official website of the Federal State Statistics Service for the Republic of Bashkortostan. (2021). https://bashstat.gks.ru/ 